\title{
Miranda, Bragança de (2008), Envios. Uma Experimentação Filosófica na Internet, Lisboa: Nova Vega
}

Pedro D. R. Costa*

É com Envios que Bragança de Miranda se entretém na Internet. São fluxos que decorrem da sua relação com o ecrã do computador, numa fusão entre os seus pensamentos, prosas e imagens sobre o mundo. São envios, incessantes e múltiplos, que tal como o autor sugere restituem a sua natureza mais imediata, "a da emissão instantânea” (p. 17). Afinal de contas, não é assim que o ciberespaço funciona?

Este livro organiza-se em duas partes. Uma primeira, que pretende lançar um certo caos ao leitor; e uma segunda, que pretende ordenar esse caos lançado pela imensidão dos pequenos textos existentes na primeira.

$\mathrm{Na}$ primeira parte, os textos não têm propriamente uma ordem, nem parecem desejar tal. O único vislumbre de arrumação é estabelecido pela ordenação alfabética dos títulos dos textos. Porém, numa análise mais cuidada e transversal, é possível identificar, sobretudo, três rodas de sentido que, ao moverem-se, "desenham um 'fio', uma linha, na estrada, traço contínuo invisível, que depende das forças e da habilidade (...) e das acidentalidades da estrada" (p. 94).

Um primeiro "fio" tem a ver com a potência das imagens. Numa boa maioria dos textos, e em todos de certa forma porque a cada texto corresponde uma imagem, são as imagens o centro das análises: imagens da infância, que corrompem o presente com a sua nostalgia (p. 22); imagens da vida, essas que são "o primeiro momento em que a vida se divide, dividindo essa vaga de fundo que tudo avassala”(p. 25); imagens-arquétipos, que estão nos filmes e em todo o lado a conspurcar a consciência (p. 31); imagens do belo ou do feio, que reproduzimos “a partir de nós próprios, a partir dos nossos sentimentos" (p. 35); imagens do medo, que nos saem pelos poros quando pressentimos que existem imagens a ganhar vida, como por exemplo os “clones" (p. 39). Mas não se trata, tal como o autor refere, de uma infinidade de imagens que nos circundam actualmente de forma caótica. Para o autor, a época das imagens foi a época teológica, onde a imagem de Deus organizava todas as outras, acima de tudo "a salvação, para onde tudo remetia, e de que dava testemunho"(p. 74). Trata-se, hoje, de uma profusão de imagens que decorre da explosão dessa "imagem absoluta" que torneava Deus e que agora se fragmenta nas várias dimensões da existência.

Um segundo "fio" tem a ver com a energia das palavras. Vários são os textos que mostram as palavras em movimento e uma escrita que tende a cobrir as imagens. Assim o é no ciberespaço. Palavras ordenadas a encetar uma escrita que rompe com o fundo, fundindo “desejo, os tipos e as imagens, criando novas e libertadoras possibilidades"(p. 13). É essa

\footnotetext{
* Sociólogo e doutorando em Ciências da Comunicação, Universidade do Minho (área de investigação - cibercultura), pcosta@mail.pt.
} 
nova escrita, que vem do fundo, que desembaciou o espelho (p. 51), o espelho da vida que está em todas as dimensões, tal como no ecrã do computador onde o autor experimenta. O que aconteceu foi que o niilismo "não abalou apenas as grandes palavras, como verdade, deus ou razão. Desprendeu-as das fortes cadeias que as acorrentavam a histórias bem precisas, que as modalizavam, diminuindo a ambiguidade que tudo atinge” (p. 109). “(...) Explodindo por dentro, a palavra surge [hoje] como um cruzamento de vidas hostis, mas que ela autoriza e que a utilizam. Deflagrando no coração daqueles que domina, a palavra acaba sempre por ser a promessa de outra vida. Ser outra, é mesmo a sua incerta vantagem"(p. 110).

Um terceiro fio é a sempre inquietante questão das ligações. Ligações entre natural e artificial, material e imaterial, antropológico e tecnológico, etc. As ligações compreendem muito mais do que as relações entre os humanos. Também os objectos, as imagens e as palavras estão relacionados com todo o tipo de propriedades. As "ligações tendem para a cristalização através de conceitos, imagens e figuras que as ocultam e dissimulam" (p. 82). Mesmo quando duram "milenarmente", é possível "verificar a efemeridade de todas as ligações” (p. 82). No entanto, o desaparecimento das velhas ligações implica novas ligações, originando novas figuras intermédias "que as estabilizam e que são capturáveis e programáveis” (p. 83), através de necessárias individuações (por exemplo, ecrã/utilizador). Na época da machina ex deus, “o que existe de brutal (...) é a ligação directa que se estabelece entre Deus (...) e as máquinas e, em geral, a técnica. (...) Muito da técnica moderna explica-se pela tentativa de criar máquinas a partir destas imagens [divinas]. Na verdade, se os deuses eram desnecessários, já era mais difícil passar sem o maravilhamento que provocavam, mais ainda quando são desejados intensamente. $\mathrm{O}$ mais arcaico coincide com o mais moderno" (p. 86). Assim, hoje enviam-se para a técnica, e para as suas capacidades de ligação e de resolução, os problemas que no passado tentavam ser resolvidos teologicamente. Agora já só se percebe a ligação entre homens e máquinas, pois os deuses embora continuem a ter força tornaram-se invisíveis. A pressão sobre a experiência, sobretudo a pressão provocada pelas máquinas digitais (e pela sua matrix), constitui um fenómeno fulcral dos nossos tempos (p. 89).

$\mathrm{Na}$ segunda parte do livro, Rumo a Citera, uma meditação final, "mais panorâmica”, encerra os envios lançando algumas luzes sobre esta experimentação filosófica na Internet. Como respeitar a dignidade do que existe? Como responder às grandes e simples perguntas de que somos portadores? Eis duas perguntas que levam o autor a concluir que para pensar o "actual” é necessário ter presente que "cada possibilidade equivale a uma dada imagem a realizar. (...) Será preciso desinserir o 'actual' da maquinaria conceptual e dialéctica que o envolve. É esta a condição para aceder pensadamente ao 'aqui e agora'” (p. 149). “(...) Desinserir o actual significa aceitar a tensão que tudo atravessa. O desejo de abolir essa tensão leva sempre à fuga do presente, sendo indiferente que se fuja para o passado ou para o futuro" (p. 150). Portanto, para o autor, "todo o humano mais não é do que uma edificação sobre a terra, assentando toda a confiança nessa construção. É a partir dela que se constroem diques, muros, citadelas, e bunkers. Mas também belos monumentos, sobrecarregados de desejos” (p. 151). Embora seja cada vez mais difícil saber o que é uma edificação, enfim, uma imagem, 
sobretudo agora que estas se tornaram mais enigmáticas do que nunca por serem produzidas pelas máquinas ópticas, o autor considera as imagens uma divisão da matéria. E “tal divisão implica uma separação virtual” (p. 153).

Ora, assim, Miranda considera que, "se a imagem divide e separa, pluraliza e aumenta os seres, também cria algo novo, alterando o aspecto da Physis, de todo o existente, de facto" (p. 154). A crise actual que vivemos é precisamente a crise das “imagens”, "e só depois a das palavras, valores e tudo mais. Toda a incerteza provém da incapacidade de as compreender" (p. 154). À medida que crescem as redes técnicas, à medida que se incrementa o controlo da vida, aumenta a necessidade de imagens que ligam redes e nomadismo de desejos que se entretêm entre imagens. "Quando as imagens surgem com a sua máxima potência acabam com toda a incerteza, e tudo se reinicia, dando tempo ao tempo (...)" (p. 157).

Vemos nesta obra, portanto, a ligação dinâmica proposta pela tríade desejo, imagens e palavras. A experiência na Internet é precisamente o resultado destas três forças, que se dinamizam através de valores nulos, acções premeditadas e prosas que irrompem do fundo. Tudo se funde nesta pós-modernidade, pois, se no passado era a palavra ou a geometria que resolviam as crises da humanidade, hoje às soluções retóricas e geométricas somam-se as possibilidades oferecidas pela matriz binária da tecnologia e pela própria subjectivação cultural que resulta da experimentação dos indivíduos e da imaginação (subjectivação suscitada, sobretudo, pelas imagens que emanam de todo o tipo de ecrãs). 